Giovanni Nadiani

Christopher Rundle

University of Bologna, Italy
2016, Vol. 13 (1), 125-140(167)

revije.ff.uni-lj.si/elope

doi: 10.4312/elope.13.1.125-140

UDC: 81 '25:7.038.531

\title{
Pianure Blues: From the Dialect of the Plains to the English of the Blues
}

\begin{abstract}
In this article the authors describe a joint performance project called Pianure Blues, in which poems in Romagnolo dialect are transposed into English and performed as blues songs, and in which songs from the Anglo-American blues/roots/folk tradition are transposed and performed as poems in Romagnolo dialect - a process they have called 'trans-staging'. A process in which they are writers and performers and, especially, translators; translators of each other's voices, stories, landscapes, rhythms and sounds as they look for the bond between places, languages and traditions that seem very distant from each other but which find a common mood and poetic language, a common aesthetic, in their performances. The authors reflect on the creative process involved and on the significance of establishing an intersemiotic dialogue between a 'minority' dialect such as Romagnolo and a 'global' language such as English, and the blues, have become.
\end{abstract}

Keywords: trans-staging; translating; transposing, poetry: music; song; blues; dialect; performance; minority languages; global languages; aesthetics of translation

\section{Pianure Blues: Od narečja ravnin do angleččine bluesa}

\section{POVZETEK}

V članku avtorja opisujeta skupni performativni projekt Pianure Blues. Gre za transpozicijo pesmi med romanjolskim narečjem in angleščino: romanjolske pesmi so prestavljene $\mathrm{v}$ angleščino in izvedene v bluesovskem žanru, medtem ko so pesmi iz anglo-ameriške tradicije bluesa ter roots in folk glasbe prestavljene in izvedene v romanjolskem narečju. Celoten proces avtorja poimenujeta "meduprizoritven" (angl. trans-staging), v njem pa sodelujeta kot pisca, izvajalca in predvsem kot prevajalca. Drug drugemu prevajata glasove, zgodbe, pokrajine, ritme in glasbo in pri tem iščeta povezave med kraji, jezikoma in tradicijami, ki so med seboj na videz zelo oddaljene, $\mathrm{v}$ resnici pa njihovo izvedbo zaznamujejo podobno razpoloženje, poetični jezik in estetika. Avtorja razmišljata o ustvarjalnem procesu, ki je prisoten pri tem projektu, ter o pomembnosti vzpostavljanja intersemiotskega dialoga med "manjšinskim" narečjem, kakršno je romanjolsko, in "globalnim" jezikom, kakršna je angleščina.

Ključne besede: trans-staging; prevajanje; transpozicija; poezija; glasba; pesem; blues; nastop; narečje; manjšinski jeziki, globalni jeziki; estetika prevajanja 


\title{
Pianure Blues: From the Dialect of the Plains to the English of the Blues
}

\author{
Orality is additive rather than subordinative; \\ aggregative rather than analytic \\ Orality is empathetic and participatory rather \\ than objectively distanced
}

(Ong 1981, 37-39, 45-46)

\section{Introduction}

There is a long tradition of collaboration between writers of all kinds and musicians and singers, both in the 'Western' tradition and in others. In this rather atypical article we will try and give an account of our own literary-musical collaboration, entitled Pianure Blues: ${ }^{1}$ a performance in which Giovanni Nadiani writes and reads in Romagnolo dialect ${ }^{2}$ original poems, and poems inspired by songs from the roots/blues/folk repertoire; and in which Chris Rundle performs these same songs as well as original songs written by him in English and inspired by Nadiani's poetry; a poetical and musical trans-staging between the dialect of the plains and the language of the blues. It is a project in which we are writers and performers and, especially, translators; translators of each other's voices, stories, landscapes, rhythms and sounds as we look for the bond between places, languages and traditions that seem very distant from each other but which find a common mood and poetic language, a common aesthetic, in our performances. At the heart of this common aesthetic are the plains (pianure in Italian or lerghi in dialect) that represent both a dominant physical reality in this part of Italy (the Po valley) as well as a shared imaginary territory in which the dialect of Romagna and the language of the blues can interact. ${ }^{3}$

\section{Romagnolo in the Key of Blues}

\subsection{The Body-Sound}

The experience of writing can best be described as the attempt to take hold of, to hold onto, and to hold in, the sensual body of the voice of the artist in a graphic corset - like the famous photo of Ellen Auerbach, The Corset, Berlin 1929. Transferring a certain text in a certain language onto paper, or onto a computer screen, is not something we experience as a choice, but rather as something that is chosen for us, that is forced on us, by the language that made us and by

\footnotetext{
Literally, blues of the plains. Cf. www.facebook.com/pianureblues.

The dialects of Italy (which cannot be considered mere vernaculars of Italian) fall into three main groups: Northern, Central, and Southern. Of these the northern group is more distinctly different from the other two than they are from each other. The Northern group has, under various influences, grown up in three families: Ligurian, Gallo-Italic, Ladin. Of these Gallo-Italic is the largest, accounting for two-thirds of the linguistic area, and roughly corresponding to the ancient sphere of the Celts. This large subgroup further subdivides into Piemontese, Lombard, Emilian and Romagnolo (see also http://www.ethnologue. com/language/rgn).

While Dante described Romagna as a large area (Purgatory xix. 92: "tra 'l Po e 'l monte e la marina e 'l Reno/between the Po, the mountains, the port and the Rhine"), it is customary now to refer to a smaller one comprising the provinces of Ravenna, Forlì-Cesena and Rimini, while part of the province of Bologna in the west belongs to Emilia, part of the province Pesaro in the south is administratively part of the Marche region and part of the mountain area belongs to the province of Florence and to the region of Tuscany.
} 
the vital idiolect that is the language of our creativity, the linguistic code that is at the heart of the historical and social context in which we live and which can be more or less prestigious and therefore active, more or less 'defeated' ${ }^{\text {' }}$ and therefore fading.

It is not our intention here to idealize creative labour but rather to underline the importance for a language of being expressed by the body-sound of its authors, of being performed by them. This is how the poet Nadiani experiences his inspiration and the ideas and stimuli that are expressed via voices of the languages that constitute his expressive being, his poetics.

\subsection{Towards a Relational Poetics of Sound}

Nadiani's poetics (both as writer and translator) are rooted in the "private wound" that was inflicted at the beginning of the 1970s on many Italian artists who were coming of age at the time by the "Great Transformation" which has completely changed the way Italians live over the last 40 years: "the reality which is ours and elsewhere, the private wound in a greater history" (D'Elia 2001, 33). This transformation affected everything from the way Italians think to the landscape around them, including, of course, their language, as Pier Paolo Pasolini has so lucidly explained (cf. Pasolini 1972, 9-28).

It was Eugenio Turri who first coined the phrase "Great Transformation" to describe the irresistible rise of a certain kind of economic system and its neo-liberalist variants, and his strikingly prophetic words seem to apply perfectly to all aspects of life in Italy today:

[...] the confused landscape of today, where order, regularity and legality have continually given way to individual intervention/initiative. Here all is haphazard, irregular, anarchic and disordered construction. It is said that this is due to the lack of planning and of laws regulating land use, but first and foremost it is the result of an inveterate and irredeemable tendency to bend any representation of the landscape to one's own particular interests and preconceptions. (Turri 1979, xii-xiii) ${ }^{5}$

Those who like Nadiani were born speaking dialect and had to be 'taught' the official language of the Italian state have experienced this violent transformation both physically and linguistically, as individuals and as part of a community, and find themselves driven to express themselves in a language that has been defeated and overcome but for which they are still a channel, a living body. And that body derives its voice from, and gives voice to, the inner laceration - along with the contradictions of the Second Modernity (cf. Beck and Mulsow 2014) - that has torn it apart, that Great Transformation that is a continual "resemiotization" of the dominant economic system. This is what constitutes the private wound that D'Elia has described. It is our voice that recounts the resemiotization of this wound, which is common to all languages to a greater or lesser degree; and it is our dialect in its original etymological sense of to dialogue, to 'talk through',

In this article the concept of 'defeated languages' will be used in a broad sense: defeated are all those languages with oral and written varieties and usage that are not acknowledged as having any cultural or functional status by their own potential speakers (see Nadiani 2011,34). These languages are often not granted the official 'political' status granted to other politically 'luckier' minority languages that are undergoing a definitive sociolinguistic patoisement (see Lafont 1976), if they are not yet dead, as described by Hagège (2002).

All translations from Italian are by the authors.

6 "Capitalism does not function as a kind of validation but as a power of semiotic over-determination [...]. Capitalism achieves its domination non just by validating the desires and needs of consumers, but above all through the resemiotization of forms of cultural identity. (Berardi 2000, 151-52). 
that expresses it. This, as the creole writer Édouard Glissant has said, involves abandoning any supposed monolingualism and writing in the presence of all the languages of the world:

But to write in the presence of all the languages of the world does not mean to know them all. It means that in this literary context, that of the relationship between poetics and the chaos-world, I cannot write in a monolingual way. It means that I do not divert and subvert my language via a synthesis but via a linguistic openness that allows me to conceive of the way the different languages of the world relate to each other, today - relations of domination, cohabitation, absorption, oppression, and erosion - as a terrible tragedy, one which my language cannot ignore (Glissant 1998, 33).

This involves expressing a sense of the totality of languages through the medium of our own individual language; it involves opening and 'translating' the wound (which includes a transformation of the language itself, perhaps to the point of it becoming unrecognizable) through a "relational poetics" (Glissant 1998, 25) of the unpredictable, experiencing the violence of alterity, of other worlds and identities and finally discovering that our being is sustained by meetings, dialogues and conflicts with other stories, other places, and other people (cf. Chambers 1996, 9). A relational poetics that is realised in an encounter with the other in a common space.

With this 'plural dialect' we find that there are sounds available to us that were unthinkable in our literary and musical monolingualism, and that are capable of expressing with an ironic and estranging vigour the physical and metaphysical malaise of the present better that any official or standardised code.

In his own work this orality or poetic-theatrical narration became a part of Nadiani's poetics, first in relation to contemporary classical composers such as Benjamin Britten (Nadiani 1986), and then in relation to the blues and jazz of the group Faxtet (Nadiani, Faxtet and Riebesehl 1997); and with it he has always sought a community to perform to, perhaps to tell of its own dissolution (Nadiani and Faxtet 2001).

Does not sound, that most subtle and adaptable of elements, constitute the place where, in the future of humanity and of the individual, the initial contact between the universe and the intelligible takes place? The voice is our desire to speak and our will to exist [...]. Coming before any form of differentiation, any form of the unsayable that can be dressed in language, the voice is a thing. We can describe its material qualities, such as its tone, timbre, breadth, depth and register [...]. In contrast to animal societies, in human society we feel our voice emerge as an object from the midst of a multiplicity of sounds, one in which the social bond is strengthened as the poetry takes shape. (Zumthor 1984, 7-9).

This relational act takes place in that magical dimension which is part of a real, physical meeting of voices, sounds and movement, and in which, for a moment perhaps, we project an offer of opening, ${ }^{7}$ of belonging, of a "plural memory that is oppositional even as it recognizes the irreparable decadence of an ideal community" (D'Elia 2001, 28). A brief flash of an otherwise impossible identity, as revealed by the voice of the poet. An identity that is made possible by the existence of a common ground in which to engage; an identity that is the product of a convergence

Although it can seem an imperialist gesture in that it imposes a path, a trajectory, a territory and a domain of perception, power and knowledge, however limited and transient, writing can also imply a refusal of any domination and be invoked as a temporary trace, an offer: an enigmatic gift contained within a language that tries to reveal an opening in ourselves and the world in which we live. (Chambers 1996, 15). 
of different bodies of knowledge and of the universal evidence that is given to us by our senses ( cf. Zumthor 1984, 315).

To return to Nadiani's own experience: his voice would weave itself within the stridently contemporary phrases of the Faxtet group and their suburban blues-jazz music (cf. Nadiani and Faxtet 2005; 2009); and his poetic-narrative 'script' would find its fullest expression in their live performances. Because it is 'out amongst the people', in streets and squares, theatres and literary circles, pubs and discos, that the narration becomes an action that is physically and bodily consumed. The performance of a work - a complex whole that is the fruit of a creative dialogue that can last for months, and that can be renewed and recreated with each new publication/ performance - is the culmination of a whole series of operations that make up the very existence of the text/script, namely, its production and exposition, its reception, conservation and repetition. The work becomes that which is communicated here and now via the text, the sounds, the rhythms and the visuals; and its text acquires a meaning that is greater than the sum of the many separate elements that are brought together to create the performance. The message is published in the strictest sense of the word. The performance becomes a creative social event, a public refusal to bow to any privatisation of language; an event to which the audience contributes with its own fundamental receptive action in which it recreates the signifying universe which is being transmitted according to its own interior configuration. In our opinion it is through this 'dialogic fusion' of instrument and voice, of that which is transmitted and received, that D'Elia's wound can be most powerfully tested and expressed.

\section{The Pianure Blues Project}

As part of Nadiani's relational poetics and his efforts to perform in dialect the voices of dispersed communities, it seemed almost natural to try to creatively transport/translate certain stylistic features and thematic topoi present in the songs that Rundle performs, which come from different Anglophone musical traditions but which are part of a 'global lingua franca' and narrate archetypal stories that are part of the storytelling traditions of so many different cultures, including Romagna. In addition to this common vein of popular narrative, the project is also inspired by the monosyllabic nature of Romagnolo dialect and the frequency with which figures such as truncation, elision, and apocopation are used - as is typical of a linguistic code that, although it can boast a strong literary written tradition, is pre-eminently oral. This dialect seems to adapt itself far more naturally to the musical, rhythmic and lexical qualities of these AngloIrish-American songs than would standard modern Italian. As Bandini has said,

[the structure of the modern musical phrase] involves the frequent use of final oxytones. And while Italian has a very reduced repertoire of oxytone words, English possesses a large number of monosyllabic words. (Bandini 1996, 31)

As well as translating the roots/blues songs that Rundle performs into Romagnolo, the idea is also to transpose/translate/trans-stage some of Nadiani's poems into the musical language of the blues (in the broadest sense of the word). This process has the added significance of being a passage from a "minority" language to one of the most dominant and "prestigious" languages in use today (cf. Hagège 2002), and the overall aim is to momentarily create, for the duration of the live performance of our mutually-inspired material, that ideal community we mentioned earlier. According to Zumthor the performance symbolizes an experience but at the same time it is the experience, one that can always be repeated and yet which is renewed each time. Semiotically 
speaking, the text announces the existence of a social group (authors-performers-listeners), given that the constant function of the performance is to unify and unite the group while staking its claim to be heard (Cf. Zumthor 1984, 32; 95; 184; 287; 293; 294). In this way the division between the artist and his/her audience is overcome by the "sound" (in the all-embracing sense we described earlier) and by his/her poetics of relation. It is in this relation that a place of otherwise merely imaginary common diversity and sociality can take shape; the place in which "when a word works, when communication takes place [...] we feel, for just an instant at least, the thrill of a shared existence" (Ronchi 2000, 14).

As far as Nadiani's approach to the trans-staging of Rundle's songs is concerned (a process which is only completed at the moment in which the poem is actually performed), the aim is not so much to create songs that can be sung in dialect as to completely rewrite the original songs in such a way as to maintain a sense of their rhythmic character. In some of his Romagnolo "transstagings" Nadiani tries to imitate the sounds of the English words without considering their meaning; while in others he translates the meaning fairly closely. English lyrics are governed by laws of prosody which are essentially oral in their nature and, as with the recital out loud of poetry, when performed contain as a form of potential all possible performances, and so can provoke/ stimulate a variety of different interpretations. While Nadiani does not ignore the musical potential of his language when translating, or better still trans-staging, into Romagnolo, what he is really interested in is capturing and reproducing a certain atmosphere, certain archetypal tales, by tapping into the narrative traditions of the region, those that in more "prestigious" languages are called "epics" or "myths". The aim is to make the songs performable in Romagnolo.

And it is this performance, the trans-staging that is enacted, which ensures that the operation is free from any ethnocentric appropriation, such as that described by Antoine Berman (2009, 25), where a translation refers wholly "to its own culture, to its own norms and values, and considers everything that is outside these - the foreign - to be negative or, at best, suitable only to be annexed or adapted." ${ }^{8}$

Rundle's approach to the trans-staging of Nadiani's poems is similarly elastic. The process begins with a few key images that evoke an atmosphere and emotion that can then be shaped into a musical mood by means of a tune and a rhythm. Once Rundle has found a musical structure for the song, the story of Nadiani's poem can then be retold; with a conscious attempt made to indirectly cite some of the traditional imagery and tropes of the blues, but in a way that is adapted to and inspired by the plains of Romagna. The aim is to produce a song that is recognizably a blues from a musical perspective, but which reveals through its text a landscape and an imagery that are fundamentally Romagnolo.

\section{Nadiani's Translations into Romagnolo}

We shall now look at little more closely, and with some examples, at how individual songs were translated and adapted, and how Nadiani has made use of certain "mythological" figures present in Romagnolo culture. We should stress that there is no conscious thematic link between these songs. Each is simply a different way of performing and staging the cultural bond that has emerged from our creative interaction.

Cf. the collection of essays in Nadiani (2015) for further reflections on the issues involved in transposing between "minority" and "majority" languages. 


\subsection{Johnny Too Bad - Zvanì Carogna}

"Johnny Too Bad" is the Jamaican reggae song that has entered into the Anglophone popular canon thanks to the success of the original, performed by The Slickers, and a number of wellknown covers, especially those by the British band UB40, US blues musician Taj Mahal and British folk singer John Martyn. It was even performed regularly in a bluegrass version by Peter Rowan. The song featured in the sound track of the iconic film The Harder They Come (1972) in which the singer Jimmy Cliff memorably plays a young man who falls from grace after a series of disappointments and setbacks and becomes a notorious local gangster. It seems natural to relate this almost mythological figure of a gangster (or rude boy), which was very present in Jamaican music at the time, to the Passatore, the Romagnolo brigand who to this day is very much alive in the collective imagination of region as a popular anti-establishment (anti-)hero (in a way that is comparable to the continued presence of Robin Hood in the English popular imagination). The Passatore was the nickname borne by Stefano Pelloni (b. 4 August 1824 in Boncellino di Bagnacavallo, d. 23 March 1851 in Russi), who was one of the most ferocious brigands to roam Romagna. He was immortalized by Giovanni Pascoli, the most important Italian poet of the turn of the 20th century, in his poem Romagna with the lines

Passator cortese re della strada re della foresta

[Gentle Passatore, king of the roads and of the forests]

This is how Nadiani has transposed the first verse and chorus into Romagnolo:

\begin{tabular}{|c|c|c|}
\hline A. Original version & $\begin{array}{l}\text { B. Nadiani's version in } \\
\text { Romagnolo }\end{array}$ & $\begin{array}{l}\text { C. Back translation into } \\
\text { English }\end{array}$ \\
\hline $\begin{array}{l}\text { Johnny Too Bad } \\
\text { Walking down the road } \\
\text { with your pistol in your waist, } \\
\text { Johnny you're too bad. } \\
\text { Walking down the road } \\
\text { with your ratchet in your } \\
\text { waist, } \\
\text { Johnny you're too bad. } \\
\text { You're just robbing and you're } \\
\text { stabbing and you're looting } \\
\text { and you're shooting. } \\
\text { Now you're too bad. } \\
\text { You're just robbing and you're } \\
\text { stabbing and you're looting } \\
\text { and you're shooting. } \\
\text { Now you're too bad. } \\
\text { [...] }\end{array}$ & $\begin{array}{l}\text { Zvanì carogna } \\
\text { A vajon par la tu strê } \\
\text { la rivultëla int e' curpet, } \\
\text { Zvanì t'si una carogna } \\
\text { a vajon par la tu strê } \\
\text { e' runchet int e' curpet } \\
\text { Zvanì t'si una carogna. } \\
\text { T'sé sól d' rubê e t'sé sól } \\
\text { d'scurghê e t'sé sól ciavê e t'sé } \\
\text { sól d'tirê. } \\
\text { T'si pröpi una carogna. } \\
\text { T'sé sól d' rubê e t'sé sól } \\
\text { d'scurghê e t'sé sól ciavê e t'sé } \\
\text { sól d'tirê } \\
\text { T'si pröpi una carogna. } \\
\text { [...] }\end{array}$ & $\begin{array}{l}\text { Bad Man Gianni } \\
\text { Strolling aimlessly down the } \\
\text { road } \\
\text { your pistol in your waistcoat } \\
\text { Gianni you're a bad man } \\
\text { Strolling aimlessly down the } \\
\text { road } \\
\text { your pistol in your waistcoat } \\
\text { Gianni you're a bad man. } \\
\text { All you do is rob and steal } \\
\text { and cut and shoot. } \\
\text { You really are a bad man. } \\
\text { All you do is rob and steal } \\
\text { and cut and shoot. } \\
\text { You really are a bad man. } \\
\text { [...] }\end{array}$ \\
\hline
\end{tabular}




\subsection{Down by Blackwaterside}

"Blackwaterside" (also known as "Blackwater Side" and "Black Waterside") is a traditional song of love and betrayal which is thought to have originated in the River Blackwater area, in Ulster. It was recorded by a number of artists during the British Folk revival in the 1960s, most memorably by Anne Briggs, who first rediscovered the song, and by Bert Jansch who learnt it from Briggs and whose guitar arrangement became the definitive version in many people's minds.' In Nadiani's transposition into Romagnolo the faithless "Irish lad" who takes his pleasure with the narrator and then abandons her becomes the "gag", the "wild redhead" in Romagnolo, who in the popular imagination is a shrewd deceiver; an attribution given to redheads in Romagna and in Italy generally. ${ }^{10}$

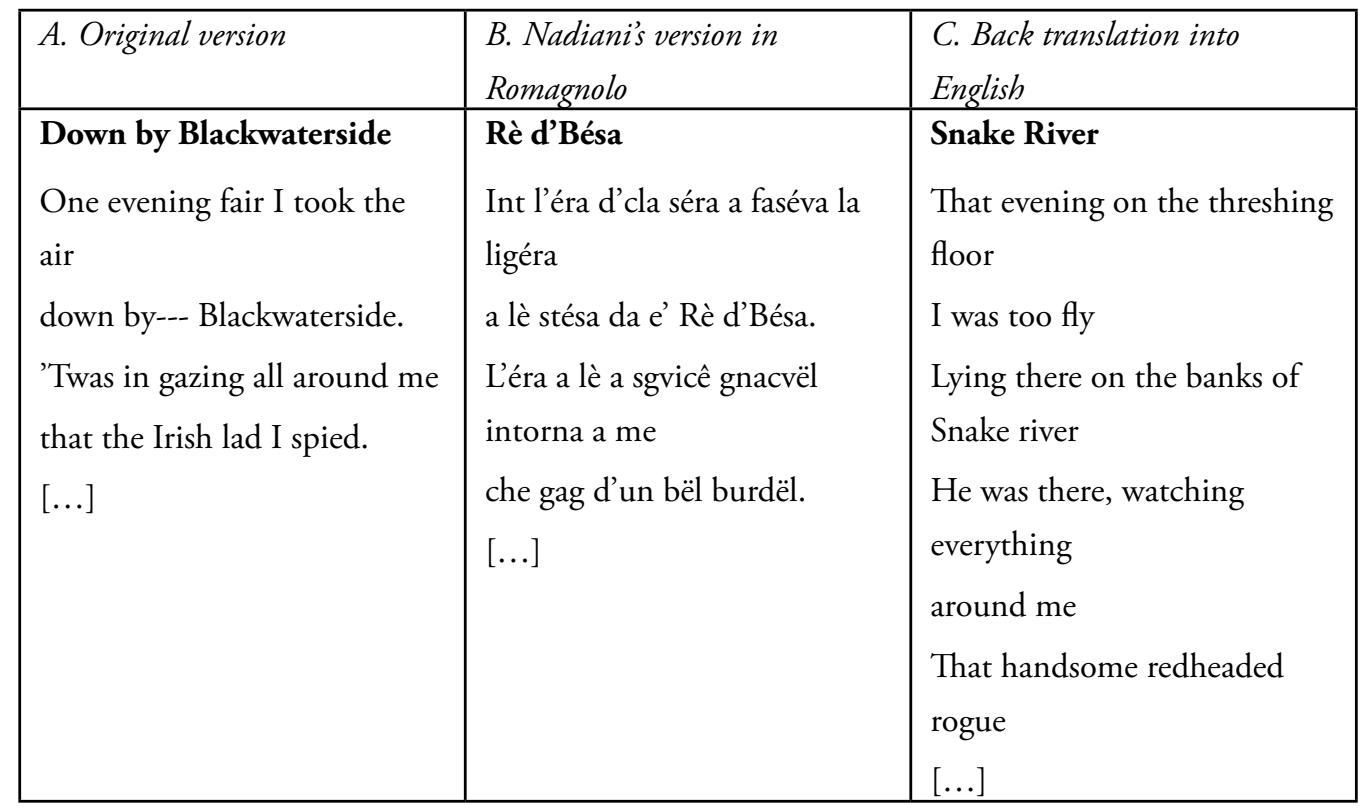

\subsection{Spike Driver's Blues}

Mississippi John Hurt's famous epic celebrating the feat of the legendary John Henry is one of the more famous songs in the American tradition that mythologize the labour and suffering that went into the conquest of the West, particularly the building of the railways. And John Henry, along with Casey Jones, is probably the greatest hero to emerge from the tales of that period. In his version Nadiani has transposed this tale of hardship on the railroads to the epopee of the "Scarriolanti" (the barrow pushers), the Romagnolo labourers who first worked in the great

\footnotetext{
9 As testament to the iconic status that both their versions have acquired, and the way in which the history of the song's revival has become representative of the British folk music scene of the time, there is even a song by Ralph McTell called "A Kiss in the Rain" that tells of how Anne Briggs taught the song to Bert Jansch. The song also became the object of a plagiarism controversy when Jimmy Page of Led Zepplin published an instrumental arrangement called "Black Mountain Side" which was remarkably close to Jansch's arrangement.

10 See, for example, the folk song Gli scariolanti sung (in Italian) in Romagna and collected by the Futurist musician Francesco Balilla Pratella which recites "Gli scariolanti belli / son tutti ingannator" [the labourers are all handsome / and they're all deceivers]; and also the maligned figure of Rosso Malpelo in the eponymous short story by Giovanni Verga.
} 
land reclamations in the Po Estuary around Ferrara and Ravenna and who then moved South in November 1884 to reclaim vast marshy areas in the region of Lazio, led by Armando Amuzzi and Nullo Baldini, two great figures of the Italian cooperative movement.

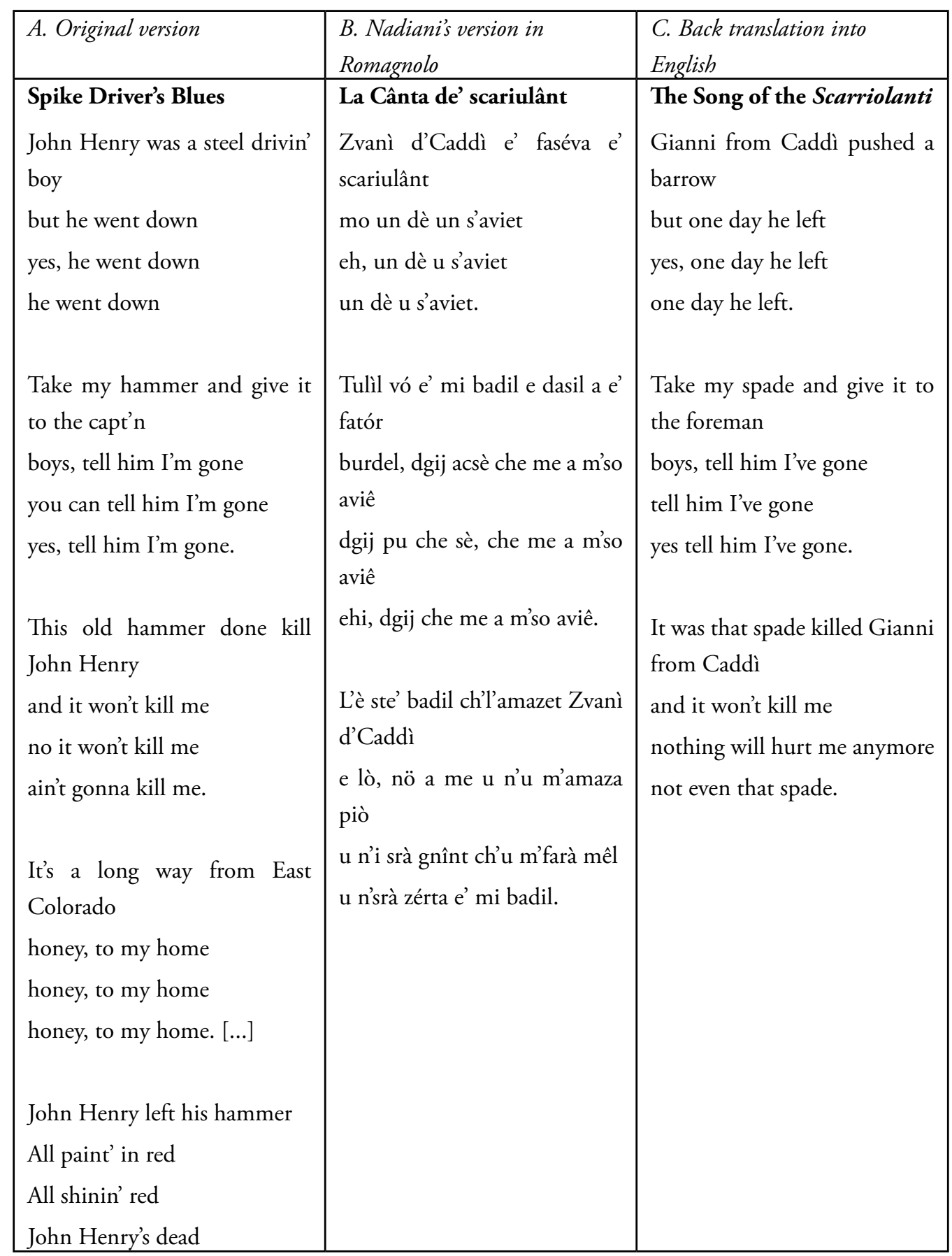




\subsection{Let's Pretend}

Another of Nadiani's adaptations takes a classic country song by Willie Nelson and transposes it into what could be defined as Romagna's own country music: "Liscio". Liscio is a form of dance music that first emerged in Romagna at the turn of the 20th century and gradually spread throughout the North of Italy, enjoying a period of particular popularity in the 1960s and 1970s with the success of the various iterations of the Casadei orchestra. It is called "liscio", which literally means smooth, because of the way couples slide their feet on the floor as they dance. It is one of the many popular genres of music, in Europe and the Americas, to be based around the Mittel-European mazurkas, waltzes and polkas. Like Country music, the theme of love betrayed is prevalent in many of the songs in the Liscio canon, and here Nadiani has written a song which is designed to be sung in the Liscio style to the tune of the Willie Nelson original.

\begin{tabular}{|c|c|c|}
\hline A. Original version & $\begin{array}{l}\text { B. Nadiani's version in } \\
\text { Romagnolo }\end{array}$ & $\begin{array}{l}\text { C. Back translation into } \\
\text { English }\end{array}$ \\
\hline Let's pretend & Fasen cont & Let's Pretend \\
\hline $\begin{array}{l}\text { Let's pretend we're strangers } \\
\text { for tonight }\end{array}$ & $\begin{array}{l}\text { Fasen cont d'rèsar di frustir } \\
\text { staséra }\end{array}$ & $\begin{array}{l}\text { Let's pretend we're strangers } \\
\text { this evening }\end{array}$ \\
\hline $\begin{array}{l}\text { Let's pretend we've never hurt } \\
\text { each other }\end{array}$ & $\begin{array}{l}\text { Fasen cont d'nò fés de' mél on } \\
\text { cun ch'l'étar }\end{array}$ & $\begin{array}{l}\text { Let's pretend we won't hurt } \\
\text { each other }\end{array}$ \\
\hline $\begin{array}{l}\text { If you'll pretend I never made } \\
\text { you cry }\end{array}$ & $\begin{array}{l}\text { Se t'fé cont par me d' nò } \\
\text { pianzar davéra }\end{array}$ & $\begin{array}{l}\text { If you'll pretend not to cry } \\
\text { at all }\end{array}$ \\
\hline $\begin{array}{l}\text { Then I'll pretend you didn't } \\
\text { find another }\end{array}$ & $\begin{array}{l}\text { Me a fegh cont ch't'a n'épa } \\
\text { brisa un étar }\end{array}$ & $\begin{array}{l}\text { I'll pretend that you don't } \\
\text { have another }\end{array}$ \\
\hline $\begin{array}{l}\text { Let's pretend our love is just } \\
\text { beginning }\end{array}$ & $\begin{array}{l}\text { Fasen cont ch'e' nòstr amór u } \\
\text { n'mura mai }\end{array}$ & $\begin{array}{l}\text { Let's pretend our love will } \\
\text { never die }\end{array}$ \\
\hline $\begin{array}{l}\text { Make believe that it was true } \\
\text { love at first sight }\end{array}$ & $\begin{array}{l}\text { Carden ch'l'è sté un amór } \\
\text { com'un zabai }\end{array}$ & $\begin{array}{l}\text { Believe that it was love at first } \\
\text { sight }\end{array}$ \\
\hline $\begin{array}{l}\text { And even though my love has } \\
\text { never really ended }\end{array}$ & $\begin{array}{l}\text { E nech se me a t'a vleva ben } \\
\text { davéra }\end{array}$ & $\begin{array}{l}\text { Even though I really loved } \\
\text { you }\end{array}$ \\
\hline $\begin{array}{l}\text { Let's pretend we're strangers } \\
\text { for tonight }\end{array}$ & $\begin{array}{l}\text { Fasen cont d'rèsar di frustir } \\
\text { staséra }\end{array}$ & $\begin{array}{l}\text { Let's pretend we're strangers } \\
\text { this evening }\end{array}$ \\
\hline $\begin{array}{l}\text { Let's pretend our love is just } \\
\text { beginning }\end{array}$ & $\begin{array}{l}\text { Fasen cont ch'e' nòstr amór u } \\
\text { n'mura mai }\end{array}$ & $\begin{array}{l}\text { Let's pretend our love will } \\
\text { never die }\end{array}$ \\
\hline $\begin{array}{l}\text { Make believe that it was true } \\
\text { love at first sight }\end{array}$ & $\begin{array}{l}\text { Carden ch'l'è sté un amor } \\
\text { com'un zabai }\end{array}$ & $\begin{array}{l}\text { Believe that it was love at first } \\
\text { sight }\end{array}$ \\
\hline $\begin{array}{l}\text { And even though my love has } \\
\text { never really ended }\end{array}$ & $\begin{array}{l}\text { E nech se me a t'a vleva ben } \\
\text { davéra }\end{array}$ & $\begin{array}{l}\text { Even though I really loved } \\
\text { you }\end{array}$ \\
\hline $\begin{array}{l}\text { Let's pretend we're strangers } \\
\text { for tonight }\end{array}$ & $\begin{array}{l}\text { Fasen cont d'rèsar di frustir } \\
\text { staséra }\end{array}$ & $\begin{array}{l}\text { Let's pretend we're strangers } \\
\text { this evening }\end{array}$ \\
\hline
\end{tabular}




\section{Rundle's Songs Inspired by Nadiani’s Poems}

As a musician and performer Rundle has always played Anglo-American-Irish folk music. His musical ear is most closely attuned to a particular combination of melody, rhythm and sound that can best be described as roots or Americana: a modern genre that fuses blues, country, folk and old-time in a single tradition of popular music that is without borders, that belongs to no single cultural or racial community, and that recalls acoustic music even when it is electrified.

\subsection{Blue Is the Colour of My Mind}

The first poem that Rundle trans-staged into song is "Blue is the Colour of my Mind" inspired by an untitled poem by Nadiani which was originally published in the collection Guardrail (Nadiani 2010). The line that first caught Rundle's imagination was "e' blù pés di nöst' pinsir" [the heavy blue of our thoughts] and this was straight away adapted to become the title of the song; but his efforts to turn the rest of the poem into a song were frustrated by what he realized was too literal an approach. Translating the poem like one might do for a literary translation was counter-productive: it produced cumbersome and overly wrought lines that were simply unsingable. The breakthrough came when Rundle realised that he must abandon any notion of translating the poem, and must simply try to write his own lines inspired by the lines of Nadiani's poems - in a way that is comparable to the relationship between subtitles and the dialogue of a film: they don't translate the dialogue, they represent it, with their own rhythm and timing.

\begin{tabular}{|c|c|c|}
\hline $\begin{array}{l}\text { A. Nadiani's poem in } \\
\text { Romagnolo }\end{array}$ & B. Translation of the poem & $\begin{array}{l}\text { C. Rundle's song inspired by the } \\
\text { poem }\end{array}$ \\
\hline [Senza titolo] & [untitled] & Blue is the colour of my mind \\
\hline nó tot cvel ch'a vlen & all we want & We watch the wind bend the grass \\
\hline l'è stêr a cvè incóra un pô & is to stand here a little longer & And feel the day slowing down. \\
\hline in sta dmenga dochmezdè & this Sunday afternoon & As clouds drift across the fields \\
\hline svincé da un vent & brushed by the wind & And head towards the town. \\
\hline ch'e' va e ch'e' ven & that comes and goes & \\
\hline in sdé cun i pi schelz & sitting bare-footed & Blue is the colour of my mind \\
\hline slunghé ins l'érba & stretched out on the grass & As I leave this day behind \\
\hline a gvardêr in so & looking up and watching & Blue is the colour of my mind \\
\hline al nuval biânchi pasturoni & the lazy white clouds & With no place left to find. \\
\hline a travarsê ona par ona & one by one drift across & \\
\hline e' blù pés di nöst' pinsir & the heavy blue of our & Lying where we can feel the earth \\
\hline a sintis adös & thoughts & Draw the aching from our bones. \\
\hline sta curent tevda & feeling this warm gust & And for a while we forget the pain \\
\hline ch'la s’sfrega j oc asré & that caresses our eyes & For which, no joy atones. \\
\hline e la stracona di nöstar dè & with the tiredness of our & \\
\hline a sghinlês veja d'int agl'ös & days & Blue is the colour $[\ldots]$ \\
\hline e par 'na vólta inluvis & slipping away from & \\
\hline ch'e' seia acsè & & Now we car \\
\hline & and to fool ourselves & This day will also end. \\
\hline
\end{tabular}


nench che dè

cun e' vent

a supiêr int la porbia

a spargujês arzir

't un étar mond that this is how it is

on that day too

with the wind

blowing up the dust

spreading us lightly

in another world
And we will cast ourselves like dust spread thinly by the wind.

Blue is the colour [...]

\subsection{Johnny's Blues}

With this song Rundle was particularly struck by the image of the whining lorries/trucks ("e' fes-c strusiê d'un mérci/the futile whistle of a truck") which imaginatively transports us straight to the A14 motorway that cuts through the middle of Romagna, from Imola to Cattolica, and projects a constant, almost imperceptible hum that is a permanent backdrop to the countryside of the plain. He was also struck by the stark evocations of empty space: the empty space of the plain itself, and the empty space that inhabits the homes and the lives of the people who live there. The key here was to succeed in writing a blues that did not fall into the trap of drawing on standard blues imagery; a genuine risk given that one's imagination could easily be drawn by the topographical similarities between the Romagna plain crossed by the A14 motorway and the American mid-West crossed by Route 66. In this respect he was helped by the way that Nadiani's imagery is rooted in small, closely observed details that do not seek to be poetic but are made so by their ability to capture the emotion of the moment. So it was enough to try and recapture these details, while simplifying them to a degree in order to make the lines singable. The result is a song that sounds like a blues song but does not read like one. The kind of pain that is expressed here is a very Romagnolo nostalgia for a time when friendship and the freedom to stroll the fields, or watch the traffic flow on the A14, were enough. The loss of that "lightness" and the sense of our own isolation that the infinite extension of the plain can force upon us is the dominant note of this poem and the song that was inspired by it.

\begin{tabular}{|c|c|c|}
\hline $\begin{array}{l}\text { A. Nadiani's poem in } \\
\text { Romagnolo }\end{array}$ & B. Translation of the poem & $\begin{array}{l}\text { C. Rundle's song inspired by the } \\
\text { poem }\end{array}$ \\
\hline arzir & light & Johnny's Blues \\
\hline \multirow{4}{*}{$\begin{array}{l}\text {... e 's a pinsaràl ste só } 1 \text { zà } \\
\text { strach } \\
\text { incaiê tra i pél dla luz i fon } \\
\text { e i fil }\end{array}$} & ... and what will this tired sun & I lean over the bridge \\
\hline & \multirow{2}{*}{ the lights and fumes of our talk } & With the sun in my eyes \\
\hline & & And I watch it go down \\
\hline & bridled by the street lamps & Between the telephone lines \\
\hline de' nostar scorar a & leaning over the whining trucks & \\
\hline spinduclon sora & that are lost & I hear the truck wheels whine \\
\hline $\begin{array}{l}\text { ch's pérd } \\
\text { chir al macnin }\end{array}$ & in the illuminated night & Beneath their heavy load \\
\hline dentr a la nöt apiêda ... & & I watch the tail lights fade \\
\hline & & And disappear down the road \\
\hline
\end{tabular}




\begin{tabular}{|c|c|c|}
\hline $\begin{array}{l}\text { (e' fes-c strusiê d'un mérci } \\
\text { pr un sgond e' svegia al } \\
\text { nöst parô } 1 \text { arziri } \\
\text { êria smarida trama al } \\
\text { câmbr avérti } \\
\text { tra agli ös spluchêdi d'un } \\
\text { palaz mai stablì) } \\
\text { ach sens arèb adës e' nöstr } \\
\text { andê zet acsè d'brazet } \\
\text { scurèndas } \\
\text { 't agli urec tot e' mond } \\
\text { zet gvardend dret d'là da } \\
\text { nó } \\
\text { s'a lasèsum chj étar e i su } \\
\text { fët } \\
\text { da par ló s'a fòsum da par } \\
\text { nó? } \\
\text { 't un étar mond }\end{array}$ & $\begin{array}{l}\text { (the futile whistle of the lorries } \\
\text { for a second awakens our light } \\
\text { words } \\
\text { stale air in open rooms } \\
\text { among the bare bones } \\
\text { of an unfinished home) } \\
\text { what is the point of our } \\
\text { strolling arm in arm whispering } \\
\text { our whole worlds in each other's } \\
\text { ear } \\
\text { standing quietly looking } \\
\text { straight ahead } \\
\text { and if we were to leave the } \\
\text { others and their stories alone? } \\
\text { what if we were alone? }\end{array}$ & $\begin{array}{l}\text { W're all alone and we're goin } \\
\text { nowhere } \\
\text { Easy words lost in time } \\
\text { Our mouths are full of words } \\
\text { That we never share } \\
\text { In the silence of rooms } \\
\text { In which we stand and stare } \\
\text { On the edge of the plain } \\
\text { Inside an empty home } \\
\text { I see through walls } \\
\text { That are bare as bones } \\
\text { We're all alone and we're goin } \\
\text { nowhere } \\
\text { Easy words lost in time }\end{array}$ \\
\hline
\end{tabular}

\subsection{Broken Old Bridge}

One of the striking things about writing a song is how an apparently simple, almost banal, line can be raised into something much more powerful by being set to a tune and a rhythm. Similarly, poetic imagery that in modern Italian might not seem particularly striking or moving can acquire a greater level of expressiveness through being phrased in dialect. Dialect and music also share the ability to carry with them a sense of popular tradition and wisdom that becomes an important part of trying to create a work that can succeed in expressing its relationship to the country that inspires this project: the plains. In in dov/Broken Old Bridge the motorway features again, but this time as a more mystical, liminal space that separates all that is secure and familiar from all that is unknown and ripe with fear. The lorries also return but this time but with an imagery that could not be further from the typical imagery of the blues. Here they slide through the thick fog like ships, in a way that will be familiar to anyone who has lived in the plains of the Po valley. The closing image is perhaps one of the more moving in Nadiani's poetry: that of the narrator waving with frozen fingers to those who are leaving or passing through. In dialect the verb for "wave" is "fê d'segn", which is actually much more interesting than the verb "to wave" and could be literally translated as "making a sign". In dialect, then, the exact significance of the gesture is a little less explicit than in English; and it was this sense of ambiguity between those who stay and those who leave which was the main inspiration in finding a tune for the song. 


\begin{tabular}{|c|c|c|}
\hline $\begin{array}{l}\text { A. Nadiani's poem in } \\
\text { Romagnolo }\end{array}$ & B. Translation of the poem & C. Rundle's song inspired by the poem \\
\hline $\begin{array}{l}\text { in dov } \\
\text { e' pê che i pont } \\
\text { i s'purta d'là da nó } \\
\text { nench se incion } \\
\text { u n'e' sa brisa in dóv } \\
\text { d's-ciota i pasa zet } \\
\text { i tir ad nebia o un fil } \\
\text { d'un'acva vérda e stila } \\
\text { ch'u s'i ved e' fond } \\
\text { e nó a cve so } \\
\text { (dida-giazul) } \\
\text { a fê d'segn a cvi } \\
\text { ch'i s'pérd 't e' vent }\end{array}$ & $\begin{array}{l}\text { where } \\
\text { it appears that the bridges } \\
\text { take us beyond ourselves } \\
\text { though no one knows where } \\
\text { beneath us the trucks } \\
\text { pass silently or a thread } \\
\text { of water, thin and so shallow } \\
\text { you can see through it } \\
\text { and we stand up here } \\
\text { (our fingers frozen) } \\
\text { waving to those } \\
\text { that are lost in the wind }\end{array}$ & $\begin{array}{l}\text { Broken Old Bridge } \\
\text { The broken old bridge stands alone } \\
\text { Across the highway, that cuts the } \\
\text { plain. } \\
\text { Grass grows through its broken } \\
\text { walls } \\
\text { worn away, by years of rain. } \\
\text { At night we feel the old bridge } \\
\text { shake } \\
\text { As the cargoes pass beneath us } \\
\text { The mist rolls slowly in their wake } \\
\text { Like waves that split between us. } \\
\text { La la la la... } \\
\text { The old men always say round here } \\
\text { No one knows, where the bridge } \\
\text { will take you } \\
\text { When its shrouded in the cold } \\
\text { damp mist } \\
\text { And crippling fear, will hold you } \\
\text { As the cold wind speaks your name. } \\
\text { They say that you may well return } \\
\text { But you won't return the same. } \\
\text { And we will wave our frozen hands } \\
\text { As the cold wind calls your name } \\
\text { And we will wave our frozen hands } \\
\text { Aat }\end{array}$ \\
\hline
\end{tabular}




\section{Conclusion}

We are clear in our minds that our use of dialect and the blues is not intended as a form of enclosure within the confines of a region or a codified musical genre, but the very opposite: each language welcomes the other into its sphere. In 2012 we took our project on a tour of Romagna, sponsored by the regional COOP Supermarket chain. The idea was for us to perform in bookshops in a series of large shopping malls in the region. At one of these events, the bookshop owner came up to us at the end of the performance and said: "When I heard that you would be coming I really couldn't imagine how poems in Romagnolo dialect and blues music could possibly go together. But now that I have listened to you I understand. It makes sense. I can't say how or why, but when you hear it, it makes sense."

Even for us it can be difficult to understand exactly how or why this collaboration works on an artistic level. In the end, we have decided that it starts with the topography that unites the plains of the Po valley and those of the Mississippi delta. From these two iconic landscapes and their histories of poverty and hard labour, there emerges an emotion that is essentially rural and popular; an emotion which in the Delta is expressed through the harsh, spell-binding language of the blues, and which in Romagna is expressed through a dialect capable of great eloquence. In our respective transpositions/trans-stagings of each other the poems and songs travel via the medium of a shared imagery and shared histories of suffering, but acquire their originality and a dimension of the unexpected through the very contemporary articulation that we try to give to these two languages (where Nadiani is a "native" of the language he is using, while Rundle is using a language adopted by choice). The more intimate and introspective character that emerges is born of the 21st century and its particular illusions and disappointments; one where two languages of the past are, perhaps, able to project an aesthetic of the future.

\section{References}

Bandini, Fernando. 1996. "Una lingua poetica di consumo". In Parole in musica. Lingua e poesia nella canzone d'autore italiana, edited by Lorenzo Coveri, 27-35. Novara: Interlinea.

Beck, Ulrich and Martin Mulsow, eds. 2014. Vergangenheit und Zukunft der Moderne. Frankfurt: Suhrkamp.

Berman, Antoine. 2003. La traduzione e la lettera o l'albergo della lontananza. Translated by Gino Giometti. Macerata: Quodlibet.

Berardi, Franco. 2001. La fabbrica dell'infelicità - New Economy e movimento del cognitariato. Roma: DeriveApprodi.

Chambers, Iain. 1996. Paesaggi migratori. Cultura e identità nell'epoca postcoloniale. Genova: Costa \& Nolan.

D’Elia, Gianni 2001. “Appunti per una critica della poetica linguistica," Il Parlar franco. Rivista di cultura dialettale e critica letteraria 1: 27-38.

Glissant, Édouard. 1998. Poetica del diverso. Roma: Meltemi.

Hagège, Claude. 2002. Morte e rinascita delle lingue. Diversità linguistica come patrimonio dell'umanità. Translated by Luisa Cortese. Milan: Feltrinelli.

Lafont, Robert. 1976. “Sur le procès de patoisement.” In Language in Sociology, edited by Albert Verdoor and Rolf Kjolseth, 125-34. Louvain: Éditions Peeters.

Nadiani, Giovanni. 1986. "Pedgh d'ombra - Da leggersi a sprazzi sul brano per chitarra solista 'Nocturnal' di 
Benjamin Britten”. In Orme d'ombra, by Giovanni Nadiani. Ravenna: Cooperativa Guidarello.

-. 2010. Guardrail. Ancona: Pequod.

—. 2011. "On the translation fallout of defeated languages: Translation and change of function of dialect in Romagna." In Translating Dialects and Languages of Minorities. Challenges and Solutions [New Trends in Translating Studies, Vol. 6], edited by Federico M. Federici. 31-48. Bern: Peter Lang.

—. 2015. Un deserto tutto per sé - Tradurre il minore. Faenza: Homeless Book.

Nadiani, Giovanni, and Faxtet. 2001. Insen... [Insieme] (Cd - Booklet). Faenza: Mobydick.

—. 2005. Romagna Garden. (Cd - Booklet). Faenza: Mobydick.

—. 2009. Best of 'E' sech'. (Cd - Booklet). Faenza: Mobydick.

Nadiani, Giovanni, Faxtet, and Ingeborg Riebesehl. 1997. Invel [In nessun posto]. (Cd - Booklet). Faenza: Mobydick.

Ong, Walter J. 1981. Orality and Literacy: The Technologizing of the Word. London: Methuen.

Pasolini, Pier Paolo. 1972. "Nuove questioni linguistiche." In Empirismo eretico, by Pier Paolo Pasolini, 9-28. Milano: Garzanti.

Ronchi, Rocco. 2000. "In nessun luogo" (Prefazione). In Sens, by Giovanni Nadiani, 9-16. Verucchio Rimini: Pazzini.

Turri, Eugenio. 1979. Semiologia del paesaggio italiano. Milano: Longanesi.

Zumthor, Paul. 1984. La presenza della voce. Introduzione alla poesia orale. Bologna: Il Mulino. 